Ю.В. Аолженко *

3ОАОТООРАИНСЬКІ КОЧІВНИКИ

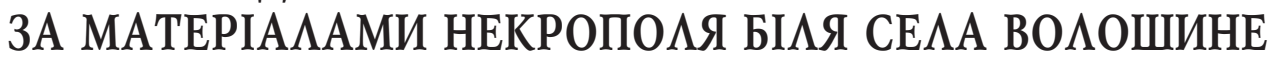

Спираючись на дані етнічної краніоскопії було опрацьовано 46 черепів з поховань Золотоординського часу, які дослідив О.Б. Супруненко поблизу с. Волошине Полтавської обл. За більшістю ознак ия серія належить до південних європеоїдів, однак окремі показники дають підставу припустити східну антропологічну домішку.

Кл ю ч о в і сло в а: Золота Орда, кочівник, Полтавщина, Пониззя Псла, с. Волошине, поховання, краніоскопія, краніологія.

Минувшина Південноруських земель другої половини XIII-XVI ст. - це важлива складова загальноукраїнської історії. Цей регіон був ядром, де почала формуватися територія сучасної України (Толочко 1998, с. 3-4).

Про золотоординські поховання на території сучасної України відомо здавніх часів (Моця 2017 , с. 24-37). Перші кочівницькі могили часів Золотої Орди випадково виявили в басейні Нижнього Псла: на початку 1870-х рр. поблизу с. Нова Кохнівка (на правобережжі Псла під Кременчуком) та наприкінці XIX ст. у Чортовій могилі на північ від с. Ревівки Кременчуцького повіту (Супруненко 2013, с. 154). Ще одне безінвентарне поховання із західною орієнтацією дослідив В.М. Щербаківський у кургані в с. Устимівці (Там само, с. 23, 97).

Пам'ятки золотоординського часу за останні роки стали добре відомими і на Полтавщині, особливо в степових районах - у нижніх течіях Сули, Псла, Сухого Кобелячка, Ворскли й Орелі (Супруненко, Приймак, Мироненко 2004, с. 5-45). Дніпровські, Псільська та Ворсклинські переправи, які діяли за доби розвинутого та на початку пізнього середньовіччя, зумовили появу тут стійбищ кочовиків, загонів, які забезпечували функціонування й охорону шляхів і переправ, можливо, функціонування митниць на берегах Дніпра, в районі затопленої Перево-

\footnotetext{
* ДОЛЖЕНКО Юрій Володимирович - молодший науковий співробітник відділу біоархеології Інституту археології НАН України, ORCID 0000-0001-98072835,yuriy_dolzhenko@ukr.net

(с) Ю.В. ДОЛЖЕНКО, 2019
}

лочної поряд із Келебердою та Кременчуком (Супруненко, Артем'єв, Маєвська 2005).

Відкриття некрополя золотоординських кочівників у курганах між сс. Волошине та Дуканичі (Дмитрівської сільської ради м. Горішні Плавні) під час досліджень на території Єристівського родовища залізистих кварцитів у 2003-2005 рр. вагомо розширило коло поховальних старожитностей кінця XIII-XVI ст. на теренах краю (Супруненко, Артем'єв, Маєвська 2005; Супруненко, Шерстюк, Пуголовок 2009). У липні-вересні 2003 р. Еристівський загін Охоронної археологічної експедиції Полтавського обласного Центру охорони та досліджень пам'яток археології на чолі 3 О.Б. Супруненком дослідив кургани в складі трьох груп на майданчику землевідводу під кар'єр Єристівського родовища залізистих кварцитів сучасного ТОВ «Еристівський гірничо-збагачувальний комбінат» (Супруненко, Артем'єв, Маєвська 2005, с. 13). Впускне поховання 2 кургану 2 (розкопки за 2004 р. групи I поблизу Волошине) (табл. 1) описав О.Б. Супруненко (Супруненко 2013, с. 158), воно розміщувалось 3 північного боку невеликого насипу, зведеного над похованням доби пізньої бронзи, покійник лежав у прямокутній ямі із округлими кутами (Супруненко, Маєвська, Артем’єв, Горбенко 2006).

Влітку 2005 р. Охоронна археологічна експедиція також провела дослідження курганів і курганоподібних насипів у складі групи II на згаданій ділянці землевідводу. Роботи велися на 7,0-7,2 км північніше та північно-східніше від м. Горішні Плавні (колишній Комсомольськ) між сс. Дуканичі, Волошине, Солонці Дмитрівської сільської ради (Кулатова, Скорий, Супруненко 2010, с. 5, 45-64).

Поховання золотоординців досліджені також поблизу сс. Солонці (Мироненко, Шилов 2003, с. 105-109), Еристівка (Супруненко, Маевская 2010 с. 295-340) та Кобелячки (Супруненко 2016, с. 81-97), (Долженко 2016, c. $98-104)$. 
Археологічні знахідки й досліджені комплекси свідчать про те, що в другій половині $\mathrm{XIV}$ ст. територія Сульсько-Орільського межиріччя була розподілена між Великим Князівством Литовським (правонаступником Русі) та Західним улусом Золотої Орди (Супруненко, Артем'єв, Маєвська 2005, с. 12).

За весь час досліджень 2003-2005 pр. відкрито понад 60 золотоординських поховань. Антропологічні матеріали з них збе- рігаються у фондах Полтавського обласного Центру охорони та досліджень пам'яток археології.

Краніологічне дослідження за черепом золотоординського кочівника XIV ст. з поховання 4 кургану 11 поблизу с. Волошине провадив С.О. Горбенко. Дослідник встановив, що це був чоловік 44-50 р., опублікував графічну реконструкцію зовнішнього вигляду кочовика та припустив його подібність до представників

Таблиия 1. Перелік та збереженість краніологічного матеріалу із с. Волошине (розкопки 2003-2012 рр.)

Table 1. List and preservation of craniological material from Voloshyne village (excavations of 2003-2012)

\begin{tabular}{|c|c|c|c|c|c|c|c|}
\hline $\begin{array}{l}\text { № } \\
\text { П/ח }\end{array}$ & $\begin{array}{c}\text { Рік } \\
\text { розкопок }\end{array}$ & Місце виявлення & $\begin{array}{l}\text { Датуван- } \\
\text { ня, ст. }\end{array}$ & Стать & $\begin{array}{c}\text { Збереженість } \\
\text { кісток (1-4 бали) }\end{array}$ & Репрезентативність & $\begin{array}{c}\text { Морфо- } \\
\text { логічний } \\
\text { вік (роки) } \\
\end{array}$ \\
\hline 1. & 2003 & $\begin{array}{l}\text { Курган } 10, \\
\text { поховання } 1\end{array}$ & XIII-XIV & $\hat{0}$ & + & $\begin{array}{l}\text { Фрагменти склепін- } \\
\text { ня черепа }\end{array}$ & $25-35$ \\
\hline 2. & $2003^{* *}$ & $\begin{array}{l}\text { Курганна група } 1 \text {, } \\
\text { курган } 11, \\
\text { поховання } 4^{* *}\end{array}$ & XIII-XIV & $\hat{0}$ & ++++ & $\begin{array}{l}\text { Повний череп, пост- } \\
\text { краніальний скелет }\end{array}$ & $60-70$ \\
\hline 3. & $\begin{array}{l}2003- \\
2004 * * *\end{array}$ & $\begin{array}{l}\text { Курганна група } 1, \\
\text { курган } 8, \\
\text { поховання } 1 \text { *** }\end{array}$ & XIV & 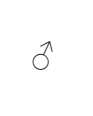 & ++++ & $\begin{array}{l}\text { Повний череп, пост- } \\
\text { краніальний скелет }\end{array}$ & $50-60 ?$ \\
\hline 4. & 2004 & $\begin{array}{l}\text { Курган } 3, \\
\text { поховання } 2\end{array}$ & $\begin{array}{l}\text { Друга по- } \\
\text { ловина } \\
\text { XIII - по- } \\
\text { чаток XIV }\end{array}$ & $\hat{0}$ & ++++ & $\begin{array}{l}\text { Повний череп, пост- } \\
\text { краніальний скелет }\end{array}$ & $35-45$ \\
\hline 5. & 2004 & $\begin{array}{l}\text { Курган 1, } \\
\text { поховання } 5\end{array}$ & XIII-XIV & $\hat{0}$ & ++++ & $\begin{array}{l}\text { Повний череп, пост- } \\
\text { краніальний скелет }\end{array}$ & $25-35$ \\
\hline 6. & 2004 & $\begin{array}{l}\text { Курган 2, } \\
\text { поховання } 16\end{array}$ & XIII-XIV & $\hat{0}$ & ++++ & $\begin{array}{l}\text { Повний череп, пост- } \\
\text { краніальний скелет }\end{array}$ & $35-45$ \\
\hline 7. & 2004 & $\begin{array}{l}\text { Курган 2, } \\
\text { поховання } 7\end{array}$ & XIII-XIV & $\hat{0}$ & ++++ & $\begin{array}{l}\text { Повний череп, пост- } \\
\text { краніальний скелет }\end{array}$ & $25-35$ \\
\hline 8. & 2004 & $\begin{array}{l}\text { Курган 2, } \\
\text { поховання } 8\end{array}$ & XIII-XIV & 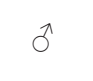 & ++++ & $\begin{array}{l}\text { Повний череп, пост- } \\
\text { краніальний скелет }\end{array}$ & $50-60$ \\
\hline 9. & 2004 & $\begin{array}{l}\text { Курган 5, } \\
\text { поховання } 1\end{array}$ & XIII-XIV & $\hat{0}$ & ++++ & $\begin{array}{l}\text { Повний череп, пост- } \\
\text { краніальний скелет }\end{array}$ & $50-60$ \\
\hline 10. & 2004 & $\begin{array}{l}\text { Курган 2, } \\
\text { поховання } 6\end{array}$ & XIII-XIV & $\hat{0}$ & ++++ & $\begin{array}{l}\text { Повний череп, пост- } \\
\text { краніальний скелет }\end{array}$ & $50-60$ \\
\hline 11. & 2004 & $\begin{array}{l}\text { Курган 1, } \\
\text { поховання } 34\end{array}$ & XIII-XIV & $\hat{0}$ & ++++ & $\begin{array}{l}\text { Повний череп, пост- } \\
\text { краніальний скелет }\end{array}$ & $25-35$ \\
\hline 12. & 2004 & $\begin{array}{l}\text { Курган 2, } \\
\text { поховання } 4\end{array}$ & XIII-XIV & 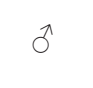 & ++++ & $\begin{array}{l}\text { Повний череп, пост- } \\
\text { краніальний скелет }\end{array}$ & $30-40$ \\
\hline 13. & 2004 & $\begin{array}{l}\text { Курган 2, } \\
\text { поховання } 12\end{array}$ & XIII-XIV & 우 & ++++ & $\begin{array}{l}\text { Повний череп, пост- } \\
\text { краніальний скелет }\end{array}$ & $30-40$ \\
\hline 14. & 2004 & $\begin{array}{l}\text { Курган 2, } \\
\text { поховання } 5\end{array}$ & XIII-XIV & 0 & + & $\begin{array}{l}\text { Фрагменти склепін- } \\
\text { ня черепа }\end{array}$ & $30-40$ \\
\hline 15. & 2004 & $\begin{array}{l}\text { Курганна група } 1, \\
\text { курган } 2, \\
\text { поховання } 15 \mathrm{a}\end{array}$ & XIII-XIV & $\hat{0}$ & + & $\begin{array}{l}\text { Фрагменти склепін- } \\
\text { ня черепа }\end{array}$ & $30-40$ \\
\hline 16. & $2004 * * * *$ & $\begin{array}{l}\text { Курган 2, } \\
\text { поховання 2**** }\end{array}$ & XIII-XIV & 우 & ++++ & $\begin{array}{l}\text { Повний череп, пост- } \\
\text { краніальний скелет }\end{array}$ & $30-40$ \\
\hline 17. & 2004 & $\begin{array}{l}\text { Курган 12, } \\
\text { поховання } 2\end{array}$ & XIII-XIV & q & ++++ & $\begin{array}{l}\text { Повний череп, пост- } \\
\text { краніальний скелет }\end{array}$ & $35-45$ \\
\hline
\end{tabular}




\begin{tabular}{|c|c|c|c|c|c|c|c|}
\hline $\begin{array}{l}\text { № } \\
\Pi / \Pi\end{array}$ & $\begin{array}{c}\text { Рік } \\
\text { розкопок }\end{array}$ & Місце виявлення & $\begin{array}{l}\text { Датуван- } \\
\text { ня, ст. }\end{array}$ & Стать & $\begin{array}{c}\text { Збереженість } \\
\text { кісток (1-4 бали) }\end{array}$ & Репрезентативність & $\begin{array}{l}\text { Морфо- } \\
\text { логічний } \\
\text { вік (роки) }\end{array}$ \\
\hline 18. & $?$ & $\begin{array}{l}\text { Курган 2, } \\
\text { поховання } 35\end{array}$ & XIII-XIV & 0 & ++++ & $\begin{array}{l}\text { Повний череп, пост- } \\
\text { краніальний скелет }\end{array}$ & $20-30$ \\
\hline 19. & $?$ & $\begin{array}{l}\text { Курган 14, } \\
\text { поховання } 1\end{array}$ & XIII-XIV & $\hat{0}$ & ++ & $\begin{array}{l}\text { Фрагменти черепа } \\
\text { та посткраніального } \\
\text { скелета }\end{array}$ & $20-30$ \\
\hline 20. & 2005 & $\begin{array}{l}\text { Курган 2, } \\
\text { поховання } 40\end{array}$ & XIII-XIV & 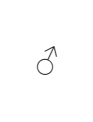 & + & $\begin{array}{l}\text { Фрагменти черепа } \\
\text { та посткраніального } \\
\text { скелета }\end{array}$ & $50-60$ \\
\hline 21. & 2005 & $\begin{array}{l}\text { Курган 2, } \\
\text { поховання } 36\end{array}$ & XIII-XIV & $\sigma^{\pi}$ & + & $\begin{array}{l}\text { Фрагменти черепа } \\
\text { та посткраніального } \\
\text { скелета }\end{array}$ & $25-35$ \\
\hline 22. & 2005 & $\begin{array}{l}\text { Курган 2, } \\
\text { поховання } 29\end{array}$ & XIII-XIV & $\sigma^{\pi}$ & ++++ & $\begin{array}{l}\text { Повний череп, пост- } \\
\text { краніальний скелет }\end{array}$ & $30-40$ \\
\hline 23. & 2005 & $\begin{array}{l}\text { Курганна група } 1, \\
\text { курган } 2, \\
\text { поховання } 37\end{array}$ & XIII-XIV & 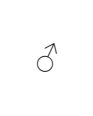 & + & $\begin{array}{l}\text { Фрагменти черепа } \\
\text { та посткраніального } \\
\text { скелета }\end{array}$ & $30-40$ \\
\hline 24. & 2012 & 1 & XIII-XIV & 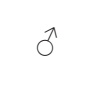 & ++++ & $\begin{array}{l}\text { Повний череп, пост- } \\
\text { краніальний скелет }\end{array}$ & $25-35$ \\
\hline 25. & 2005 & $\begin{array}{l}\text { Курган 2, } \\
\text { поховання } 30\end{array}$ & XIII-XIV & $\hat{0}$ & ++ & $\begin{array}{l}\text { Фрагменти черепа } \\
\text { та посткраніального } \\
\text { скелета }\end{array}$ & $35-45$ \\
\hline 26. & 2005 & $\begin{array}{l}\text { Курганна група } 1, \\
\text { курган } 2, \\
\text { поховання } 39\end{array}$ & XIII-XIV & 0 & + & $\begin{array}{l}\text { Фрагменти черепа } \\
\text { та посткраніального } \\
\text { скелета }\end{array}$ & $30-40$ \\
\hline 27. & $2005 ?$ & $\begin{array}{l}\text { Курганна група } 1, \\
\text { курган } 2, \\
\text { поховання } 59\end{array}$ & XIII-XIV & $\delta^{\lambda} ?$ & + & $\begin{array}{l}\text { Фрагменти черепа } \\
\text { та посткраніального } \\
\text { скелета }\end{array}$ & $?$ \\
\hline 28. & $2005 ?$ & $\begin{array}{l}\text { Курган 2, } \\
\text { поховання } 25\end{array}$ & XIII-XIV & 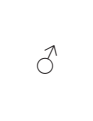 & ++ & $\begin{array}{l}\text { Фрагменти черепа } \\
\text { та посткраніального } \\
\text { скелета }\end{array}$ & $45-55$ \\
\hline 29. & $2005 ?$ & $\begin{array}{l}\text { Курган 13, } \\
\text { поховання } 1\end{array}$ & XIII-XIV & 우 & ++++ & $\begin{array}{l}\text { Повний череп, пост- } \\
\text { краніальний скелет }\end{array}$ & $25-35$ \\
\hline 30. & $2005 ?$ & $\begin{array}{l}\text { Курганна група } 1, \\
\text { курган } 2, \\
\text { поховання } 26\end{array}$ & XIII-XIV & 우 & ++++ & $\begin{array}{l}\text { Повний череп, пост- } \\
\text { краніальний скелет }\end{array}$ & $20-30$ \\
\hline 31. & $2005 ?$ & $\begin{array}{l}\text { Курган 13, } \\
\text { поховання } 1\end{array}$ & XIII-XIV & 우 & + & $\begin{array}{l}\text { Фрагменти чере- } \\
\text { па, посткраніальний } \\
\text { скелет }\end{array}$ & $25-30$ \\
\hline 32. & 2005 & $\begin{array}{l}\text { Курганна група } 1, \\
\text { курган } 2, \\
\text { поховання } 42\end{array}$ & XIII-XIV & 우 & ++++ & $\begin{array}{l}\text { Повний череп, пост- } \\
\text { краніальний скелет }\end{array}$ & $18-25$ \\
\hline 33. & 2005 & $\begin{array}{l}\text { Курган 2, } \\
\text { поховання } 43\end{array}$ & XIII-XIV & 우 & + & $\begin{array}{l}\text { Фрагменти чере- } \\
\text { па, посткраніальний } \\
\text { скелет }\end{array}$ & $30-40$ \\
\hline 34. & $2005 ?$ & $\begin{array}{l}\text { Курган 2, } \\
\text { поховання } 57\end{array}$ & XIII-XIV & 우 & ++++ & $\begin{array}{l}\text { Повний череп, пост- } \\
\text { краніальний скелет }\end{array}$ & $35-45$ \\
\hline 35. & 2005 & $\begin{array}{l}\text { Курган 2, } \\
\text { поховання } 32\end{array}$ & XIII-XIV & 우 & ++++ & $\begin{array}{l}\text { Повний череп, пост- } \\
\text { краніальний скелет }\end{array}$ & $50-60$ \\
\hline 36. & $2005 ?$ & $\begin{array}{l}\text { Курган 2, } \\
\text { поховання } 28\end{array}$ & XIII-XIV & 우 & ++++ & $\begin{array}{l}\text { Повний череп, пост- } \\
\text { краніальний скелет }\end{array}$ & $25-35$ \\
\hline 37. & $2005 ?$ & $\begin{array}{l}\text { Курган 2, } \\
\text { поховання } 52\end{array}$ & XIII-XIV & q & ++++ & $\begin{array}{l}\text { Повний череп, пост- } \\
\text { краніальний скелет }\end{array}$ & $25-35$ \\
\hline 38. & $2005 ?$ & $\begin{array}{l}\text { Курган 2, } \\
\text { поховання } 44\end{array}$ & XIII-XIV & q & +++ & $\begin{array}{l}\text { Повний череп, пост- } \\
\text { краніальний скелет }\end{array}$ & $20-30$ \\
\hline
\end{tabular}




\begin{tabular}{|c|c|c|c|c|c|c|c|}
\hline $\begin{array}{l}\text { № } \\
\Pi / \Pi\end{array}$ & $\begin{array}{c}\text { Рік } \\
\text { розкопок }\end{array}$ & Місце виявлення & $\begin{array}{l}\text { Датуван- } \\
\text { ня, ст. }\end{array}$ & Стать & $\begin{array}{c}\text { Збереженість } \\
\text { кісток (1-4 бали) }\end{array}$ & Репрезентативність & $\begin{array}{l}\text { Морфо- } \\
\text { логічний } \\
\text { вік (роки) }\end{array}$ \\
\hline 39. & $2005 ?$ & $\begin{array}{l}\text { Курган 2, } \\
\text { поховання } 27\end{array}$ & XIII-XIV & 우 & + & $\begin{array}{l}\text { Фрагменти чере- } \\
\text { па, посткраніальний } \\
\text { скелет }\end{array}$ & $35-45$ \\
\hline 40. & $2005 ?$ & $\begin{array}{l}\text { Курган 2, } \\
\text { поховання } 31\end{array}$ & XIII-XIV & o & ++++ & $\begin{array}{l}\text { Повний череп, пост- } \\
\text { краніальний скелет }\end{array}$ & $16-20$ \\
\hline 41. & $2005 ?$ & $\begin{array}{l}\text { Курган 2, } \\
\text { поховання } 22\end{array}$ & XIII-XIV & 우 & ++++ & $\begin{array}{l}\text { Повний череп, пост- } \\
\text { краніальний скелет }\end{array}$ & $25-35$ \\
\hline 42. & $2005 ?$ & $\begin{array}{l}\text { Курган 14, } \\
\text { поховання } 3\end{array}$ & XIII-XIV & o & ++++ & $\begin{array}{l}\text { Повний череп, пост- } \\
\text { краніальний скелет }\end{array}$ & $25-35$ \\
\hline 43. & $2005 ?$ & $\begin{array}{l}\text { Курган } 2, \\
\text { поховання } 53\end{array}$ & XIII-XIV & 0 & ++++ & $\begin{array}{l}\text { Повний череп, пост- } \\
\text { краніальний скелет }\end{array}$ & $30-40$ \\
\hline 44. & $2005 ?$ & $\begin{array}{l}\text { Курган 2, } \\
\text { поховання } 24\end{array}$ & XIII-XIV & q & ++ & $\begin{array}{l}\text { Череп без нижньої } \\
\text { щелепи, посткраніа- } \\
\text { льний скелет }\end{array}$ & $20-30$ \\
\hline 45. & $2005^{*}$ & $\begin{array}{l}\text { Курганна група } 2 \text {, } \\
\text { курган } 1 \text {, } \\
\text { поховання } 1 *\end{array}$ & XIII-XIV & 우 & + & $\begin{array}{l}\text { Фрагменти } \\
\text { черепа, посткрані- } \\
\text { альний скелет }\end{array}$ & $30-40$ \\
\hline 46. & 2012 & $\begin{array}{l}\text { Курган } 5 \text {, } \\
\text { поховання } 1\end{array}$ & XIII-XIV & 우 & ++ & $\begin{array}{l}\text { Фрагменти } \\
\text { черепа, посткрані- } \\
\text { альний скелет }\end{array}$ & $30-40$ \\
\hline
\end{tabular}

П р и м і т ки. Умовні позначення: 스 - чоловік; q - жінка; * за: Кулатова, Скорий, Супруненко 2010, с. 45-64. ** за: Горбенко 2006, с. 113-135. *** за: Крупа 2005, с. 103-107. **** за: Супруненко 2013, с. 158.

Таблиия 2. Частоти та радіани краніоскопічних ознак у краніологічній серії Волошине XIII-XIV ст. та порівняльні дані, \%

Table 2. Frequency of cranioscopical features in craniological series of $13^{\text {th }}-14^{\text {th }}$ c. from Voloshyne village and comparative data, $\%$

\begin{tabular}{|c|c|c|c|c|c|c|c|c|c|c|c|c|c|c|}
\hline $\begin{array}{l}\text { № } \\
\text { п/ா }\end{array}$ & Серія & $\begin{array}{l}\text { Сто- } \\
\text { ліття } \\
\end{array}$ & ПІ & $\begin{array}{l}\text { Раді- } \\
\text { ани }\end{array}$ & $\begin{array}{l}\text { ПОВ- } \\
\text { II }\end{array}$ & Рад. & ЗВШ & Рад. & КВШ & Рад. & ІППШ & Рад. & $\mathrm{HO}$ & Рад. \\
\hline 1. & Волошине & $\begin{array}{l}\text { XIII- } \\
\text { XIV }\end{array}$ & $\begin{array}{l}33,3 \\
(74)\end{array}$ & 1,240 & $\begin{array}{l}27,7 \\
(54)\end{array}$ & 1,117 & $\begin{array}{l}6,0 \\
(66)\end{array}$ & 0,518 & $\begin{array}{l}46,7 \\
(130)\end{array}$ & 1,506 & $\begin{array}{l}63,5 \\
(74)\end{array}$ & 1,842 & $\begin{array}{l}38,8 \\
(90)\end{array}$ & 1,349 \\
\hline 2. & $\begin{array}{l}\text { Воїнська } \\
\text { Гребля } \\
\text { (м. Воїнь) }\end{array}$ & $\begin{array}{l}\mathrm{XI}- \\
\mathrm{XIV}\end{array}$ & $\begin{array}{l}0 \\
(63)\end{array}$ & 0,270 & $\begin{array}{l}50,0 \\
(32)\end{array}$ & 1,472 & $\begin{array}{l}9,5 \\
(42)\end{array}$ & 0,602 & $\begin{array}{l}48,6 \\
(62)\end{array}$ & 1,402 & $\begin{array}{l}87,8 \\
(41)\end{array}$ & 2,351 & $\begin{array}{l}46,0 \\
(63)\end{array}$ & 1,417 \\
\hline 3. & $\begin{array}{l}\text { Переяслав } \\
\text { та район } \\
\text { (збірна } \\
\text { серія) }\end{array}$ & $\begin{array}{l}\text { XII- } \\
\text { XV }\end{array}$ & $\begin{array}{l}14,2 \\
(31)\end{array}$ & 0,826 & $\begin{array}{l}29,1 \\
(24)\end{array}$ & 1,155 & $\begin{array}{l}4,0 \\
(25)\end{array}$ & 0,466 & $\begin{array}{l}50,0 \\
(52)\end{array}$ & 1,517 & $\begin{array}{l}56,2 \\
(32)\end{array}$ & 1,693 & $\begin{array}{l}30,0 \\
(33)\end{array}$ & 1,175 \\
\hline 4. & $\begin{array}{l}\text { Благові- } \\
\text { щенка }\end{array}$ & $\begin{array}{l}\text { XII- } \\
\text { XIV }\end{array}$ & $\begin{array}{l}0 \\
(38)\end{array}$ & 0,395 & $\begin{array}{l}48,4 \\
(31)\end{array}$ & 1,539 & $\begin{array}{l}9,7 \\
(41)\end{array}$ & 0,659 & $\begin{array}{l}8,3 \\
(50)\end{array}$ & 0,590 & $\begin{array}{l}82,7 \\
(29)\end{array}$ & 2,264 & $\begin{array}{l}22,5 \\
(40)\end{array}$ & 1,001 \\
\hline 5. & Каїри* & $\begin{array}{l}\text { XI- } \\
\text { XIII? }\end{array}$ & $\begin{array}{l}17,6 \\
(33)\end{array}$ & 0,902 & $\begin{array}{l}26,9 \\
(26)\end{array}$ & 1,106 & $\begin{array}{l}10,7 \\
(28)\end{array}$ & 0,699 & $\begin{array}{l}62,9 \\
(46)\end{array}$ & 1,823 & $\begin{array}{l}48,0 \\
(25)\end{array}$ & 1,532 & $\begin{array}{l}19,4 \\
(36)\end{array}$ & 0,929 \\
\hline 6. & $\begin{array}{l}\text { Мамай } \\
\text { Сурка* }\end{array}$ & $\begin{array}{l}\text { XIII- } \\
\text { XIV? }\end{array}$ & $\begin{array}{l}30,7 \\
(86)\end{array}$ & 1,188 & $\begin{array}{l}35,5 \\
(76)\end{array}$ & 1,280 & $\begin{array}{l}8,7 \\
(91)\end{array}$ & 0,614 & $\begin{array}{l}45,4 \\
(178)\end{array}$ & 1,478 & $\begin{array}{l}63,0 \\
(73)\end{array}$ & 1,831 & $\begin{array}{l}40,9 \\
(88)\end{array}$ & 1,390 \\
\hline 7. & Кам’янка & $\begin{array}{l}\mathrm{X}- \\
\mathrm{XII}\end{array}$ & $\begin{array}{l}10,5 \\
(72)\end{array}$ & 0,708 & $\begin{array}{l}63,0 \\
(65)\end{array}$ & 1,832 & $\begin{array}{l}8,1 \\
(74)\end{array}$ & 0,593 & $\begin{array}{l}48,5 \\
(151)\end{array}$ & 1,540 & $\begin{array}{l}57,7 \\
(71)\end{array}$ & 1,725 & $\begin{array}{l}43,8 \\
(89)\end{array}$ & 1,448 \\
\hline 8. & $\begin{array}{l}\text { Половці } \\
\text { (Пришиб, } \\
\text { Сміле, } \\
\text { Знам'янка) }\end{array}$ & $\begin{array}{l}\text { XI- } \\
\text { XIII }\end{array}$ & $\begin{array}{l}37,5 \\
(27)\end{array}$ & 1,330 & $\begin{array}{l}20,8 \\
(24)\end{array}$ & 0,970 & $\begin{array}{l}14,7 \\
(34)\end{array}$ & 0,808 & $\begin{array}{l}48,6 \\
(68)\end{array}$ & 1,543 & $\begin{array}{l}56,6 \\
(30)\end{array}$ & 1,701 & $\begin{array}{l}37,5 \\
(40)\end{array}$ & 1,323 \\
\hline
\end{tabular}

П р и м і т к и. В дужках вказана загальна кількість спостережень. Рад. - Радіани. * - попередні дані. 


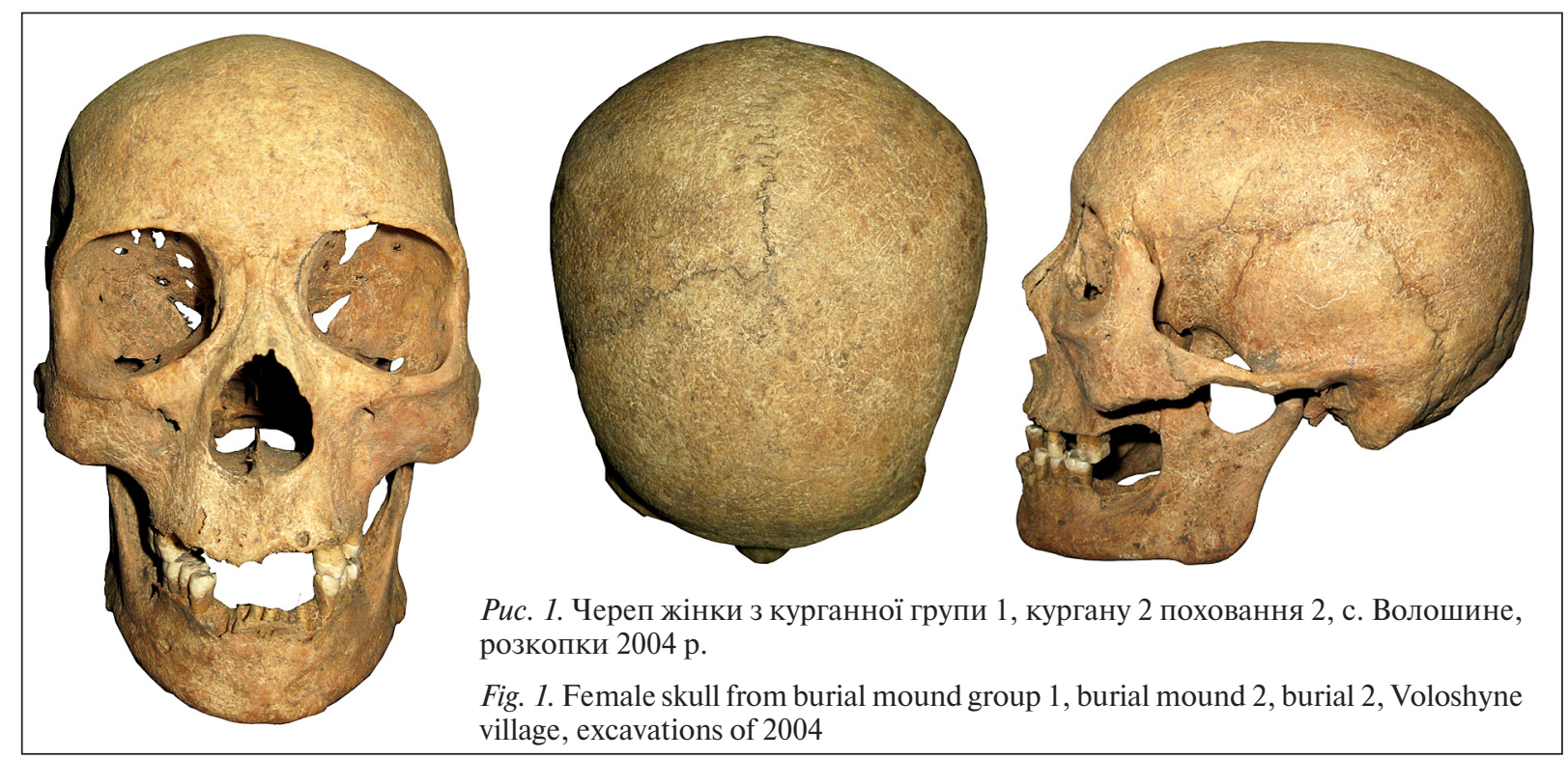

алано-хозарських племен (Горбенко 2006, додаток 2, с. 113-135).

Матеріали і методика. Всього 3 курганів с. Волошине автор дослідив 46 черепів, придатних для краніоскопії (табл. 1) (23 чоловічих і 22 жіночих, один - невизначеної статі). Черепи дітей та підлітків у цій роботі не розглядатимуться, вони потребують додаткового вивчення за іншими методиками. Статевовікові визначення та опрацювання антропологічного матеріалу проводилися в Центрі охорони та досліджень пам'яток археології ${ }^{~}$.

Для характеристики краніологічної серії XIII-XVI ст. з с. Волошине було використано методику О.Г. Козінцева (Kozintsev 1992), яка відноситься до однієї з галузей расознавства етнічної краніоскопії (Козинцев 1988). Для порівняння груп за дискретно-варіативними ознаками використовувались комп'ютерні програми, які розробили Б.О. та О.Г. Козінцеви 1991 р. (Санкина, Моисеев 2006). Було застосовано метод головних компонент (ГК) (за стандартними шістьма краніоскопічними ознаками), одну з моделей факторного аналізу (Дерябин 2008, с. 76-117). При цьому вдалося виокремити три ГК з власними числами, які перевищують одиницю. Аналіз вівся за допомогою статистичної програми РССОМР, котра повністю аналізує ГК та вирішує зворотне факторне завдання, а саме: знаходить значення кожної компоненти для кожного об'єкта. Програма PCDENDU виконує кластерний

\footnotetext{
Щиро дякую О.Б. Супруненку та А.В. Артем’єву за можливість дослідити антропологічний матеріал із с. Волошине, допомогу та консультації.
}

аналіз матриці евклідових дистанцій незваженим парно-груповим методом (Дерябин 2008, с. 230-276). Графіки побудовані за результатами аналізу методом ГК, використовуючи координати центроїдів трьох перших векторів. Підрахування частот у відсотках та перетворення їх на радіани з метою стабілізації дисперсії проводились завдяки застосуванням авторської комп'ютерної програми А.В. Громова (Громов, Моисеев 2004).

Краніоскопічна характеристика. Під час дослідження 23 чоловічих і 22 жіночих (рис. 1) черепів XIII-XIV ст. із с. Волошине враховувалися шість краніоскопічних ознак: індекс поперечного піднебінного шва (ІППШ); клиноподібний верхньощелепний шов (КВШ); задньовиличний шов (ЗВШ); підорбітний візерунок типу II (ПОВ-ІІ); надорбітні отвори (НО); потиличний індекс (ПІ). Чоловічі та жіночі черепи розглядаються спільно. Для ПІ, ЗВШ, ПОВ-II, ІППШ та НО дані складалися без урахування статі, для КВШ вираховувались півсуми чоловічих і жіночих значень. Частоти ознак аналізованих восьми груп XI-XIV ст. подано в табл. 2.

Відомо, що частота, з якою ці ознаки трапляються в різних групах, варіює залежно від расової належності, а отже, може служити одним із критеріїв расової диференціації. Зокрема, до комплексу ознак, характерних для європеоїдних груп, входять низькі значення ПІ, ЗВШ, НО та високі індекси ІППШ. Азійські групи характеризуються протилежним комплексом краніоскопічних ознак (Моисеев, Широбоков, Крийска и др. 2013, с. 71-79).

На черепах з могильника Волошине за відсотковою часткою ПІ підвищений (східний 
напрям зв’язку); ЗВШ на черепах досліджуваної групи відсутній, що вказує на ії європеоїдність; За даними О.Г. Козінцева (Козинцев 1988 , с. 55), КВШ загалом трапляється частіше у європеоїдів, ніж у монголоїдів. Збірна серія чоловічих і жіночих черепів з с. Волошине виявилася з помірним показником КВШ (46,7 \%), що вказує на европеоїдність. Частота ПОВ-II на черепах із Волошиного низька $27,7 \%$, що свідчить про приналежність групи до південних європеоїдів. ІППШ у досліджуваної групи помірний $(63,5 \%)$. Оскільки незважене середнє цієї ознаки для європеоїдів дорівнює 70,5 \%, а для монголоїдів - 49,9 \% (Козинцев 1988, с. 110), можна вважати досліджувану серію такою, яка перебуває на межі між європеоїдними та монголоїдними групами за цією ознакою, однак схиляється більше до європеоїдних популяцій. Відсотки НО (Томашевич 1988, с. 119-128) на черепах із Волошиного підвищені, що вказує на східний вектор зв'язків цієї групи людей (табл. 2). Таким чином, три ознаки з п'яти у досліджених черепів чітко вказують на належність серії до європеоїдів (можливо, південної гілки). Дві ознаки дають підстави припустити східну антропологічну домішку, і ще за однією краніоскопічною ознакою вибірка з с. Волошине займає проміжне положення.

Порівняльна характеристика антропологічних особливостей похованих у курганному комплексі Волошине. Для виявлення основних напрямків генетичних зв'язків популяції з Волошиного та визначення іiі місця в системі расових та антропологічних типів населення Східної Європи та Азії XII-XVI ст. проведено міжгруповий багатовимірний аналіз методом головних компонент (Дерябин 2008, с. 76117).

До порівняльного аналізу ГК залучалися як синхронні слов'янські, так і численні групи раннього середньовіччя. Зокрема, вибірки 3 території України: Каменка (Кам'янка) X-XII ст. (45 черепів) (Єльников 2002, с. 72; Козловський 1992, с. 120; Кондукторова 1957, с. 55-59; Литвинова 2008, с. 148-153; Плетнева 1958, с. 185 ; Рутківська 1975, с. 440; Сегеда 2001, с. 174-175); Каїри (23 черепа) (Ельников 2006; Зіневич 1960, с. 98-101); Мамай Сурка XII-XV ст. (44 черепа) (Бодянський 1977, Литвинова 2012, с. 21-35, Ельников 2006); Благовіщенка (23 черепа) (Круц, Литвинова 2002, с. 115-117; Круц, Литвинова 2003, с. 143-149); Воїнь (35 черепів) (Богусевич, Гончаров, Довженок та ін. 1957; Довженок,
Гончаров, Юра 1966; Dolzhenko 2015, s. 95102); збірна серія XIII-XVI ст. з ПереяславХмельницького р-ну. (Сомкова долина, Комарівка в уроч. Васильків, Соснова), (Колибенко 2005; Колибенко 2015, с. 156-168; Сикорский, Махно, Бузян 1978), половці ХІ-ХІІІ ст. з Луганської обл. (Шепель 1992, с. 66; Братченко, Квитницкий, Швецов 2012; Долженко 2012, c. 137-140). Крим: Солхат, караїми, кримські татари (Громов, Моисеев 2004).

3 Башкирії (Башкортостану) представлено Бірськ (Башкирія), Алтаю - група Курайська долина (Курайський степ - міжгірська улоговина на південному сході Республіки Алтай), серія Алтай. Забайкалля - Сайантуйська культура (Забайкалля), Хакасії - серія Койбали (етнографічна група хакаського народу), качинці (етнографічна група хакасів). Новосибірське, Томське Приоб'я, Ур-Бедари, Кайбелево, Чаати, Приіртишшя, середньовічні Бараби, калмики, татари курдакско-саргатські, шорці Абакану, турки анатолійські, чулмиці ЯЯ-Кия, чулмиці Тургай-Балагачево (Громов, Моисеев 2004, с. 219). 3 Волгоградської та Астраханської обл. представлені такі вибірки як Маячний бугор, Вакурівський бугор, Красноярське городище (Балабанова, Перерва, Зубарева 2011, с. 40-44, 49-51; Балабанова, Перерва 2013). Царівське городище (Громов, Моисеев 2004, с. 219-220). Загалом до порівняльного аналізу залучено 34 групи.

На першу ГК припадає фактично 29,9 \% загальної дисперсії (табл. 3). При класифікації груп найбільш значні навантаження в ГК І отримали такі ознаки: ПІ (додатні значення), ЗВШ, ПОВ-II. Вони роз'єднують серії за даною компонентою, що відображено і в розташуванні груп уздовж осі ГК I (рис. 2). Серія Волошине за рахунок великих від'ємних значень першої компоненти $(-1,178)$ подібна до черепів з могильника

Таблиця 3. Коефіцієнти кореляції краніоскопічних ознак з ГК для 34 групи (чоловіки та жінки)

Table 3. Correlation coefficients of cranioscopical features to main components for 34 groups (men and women)

\begin{tabular}{|l|l|c|c|}
\hline \multicolumn{1}{|c|}{ Ознаки } & \multicolumn{1}{c|}{ I ГK } & II ГK & III ГK \\
\hline ПІ & $\mathbf{0 , 6 2 9}$ & $-0,483$ & 0,055 \\
КВШ & $-0,309$ & $\mathbf{- 0 , 6 7 7}$ & 0,522 \\
ЗВШ & $\mathbf{0 , 6 1 6}$ & $-0,043$ & $-0,012$ \\
ПОВ-II & $\mathbf{0 , 6 9 7}$ & 0,414 & $-0,129$ \\
ІППШ & $-0,420$ & $\mathbf{0 , 6 8 1}$ & 0,378 \\
НО & 0,511 & 0,234 & $\mathbf{0 , 7 4 9}$ \\
Власне число & 1,795 & 1,383 & 0,997 \\
Частка загальної & 29,915 & 23,046 & 16,611 \\
мінливості, \% & & & \\
\hline
\end{tabular}




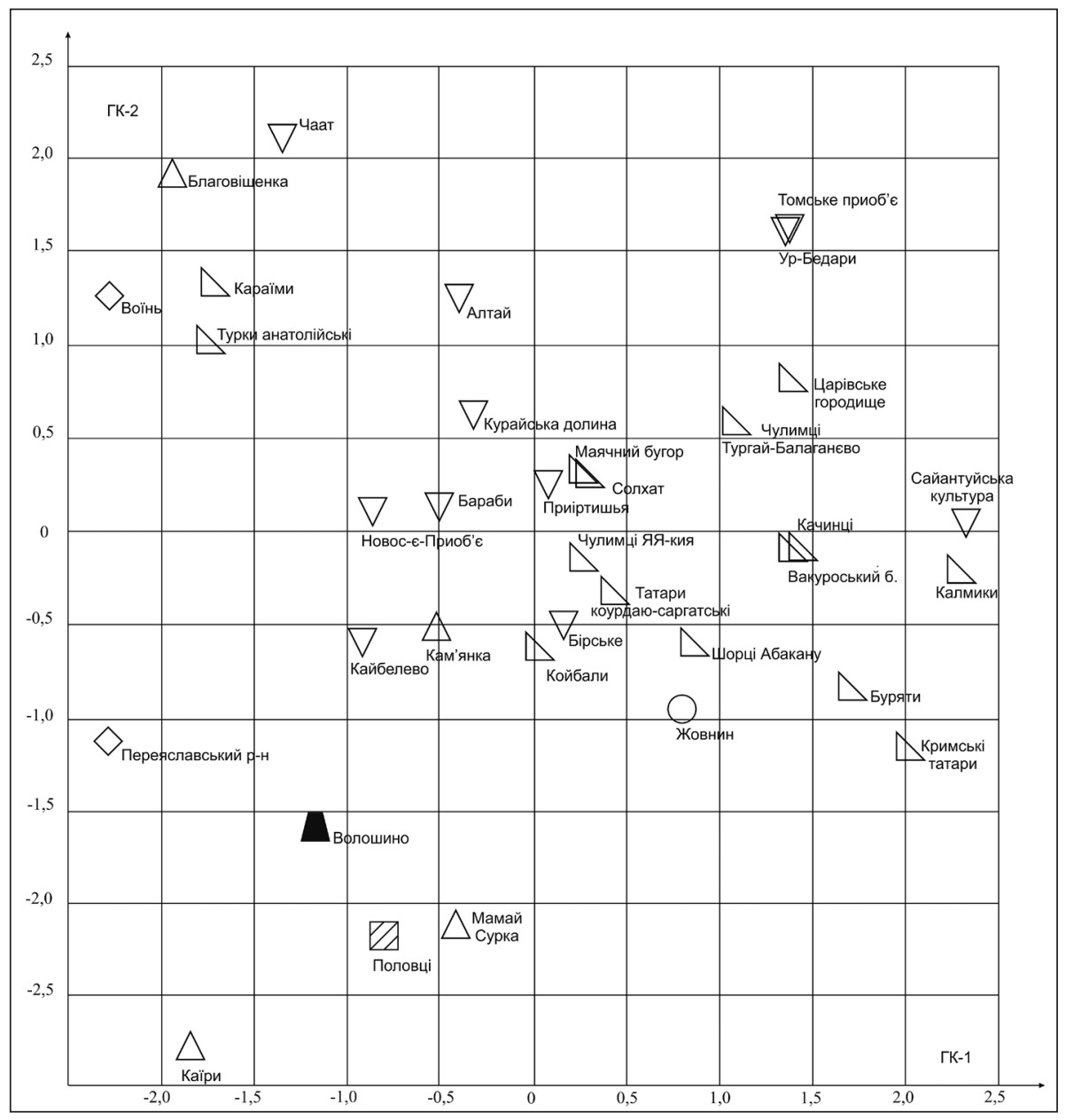

Puc. 2. Розташування 34 краніологічних груп XII-XVIII ст. у просторі I і II ГК. $\Delta-$ групи Нижньої Наддніпрянщини; $\diamond-$ слов’янські групи Дніпровського Лівобережжя; o - групи пізнього середньовіччя; $\vee$ - групи раннього та розвинутого середньовіччя

Fig. 2. Disposition of 34 craniological groups of $12^{\text {th }}-18^{\text {th }} \mathrm{c}$. in space of the $1^{\text {st }}$ and the $2^{\text {nd }}$ main components. $\Delta-$ groups of the Lower Dnieper Basin; $\diamond-$ Slavonic groups from the Left Bank of the Dnieper; $\circ$ - late medieval groups; $\vee$ - early and middle medieval groups

Кайбелеве $(-0,903)$, Новосибірського Приоб'я $(-0,848)$, половців з Луганської обл. $(-0,809)$ та меншою мірою - Нижньої Наддніпрянщини, Каїрів $(-1,849)$. Населення, яке залишило могильник Каїри, на думку його дослідника А.О. Козловського (Козловський 1992, с. 120, 159-162), має неслов'янське походження, причому жінки становили місцеву частину населення, а чоловіки - прийшлу. Л.В. Литвинова вважає, що матеріали з грунтового могильника Каїри, як і Мамай Сурка, Благовіщенка, Кам'янка свідчить про неоднорідний склад та наявність різних краніологічних варіантів, що не виходять за межі європеоїдної раси. На думку цієї дослідниці, морфологічний тип, представлений у перерахованих серіях, належить до південних європеоїдних груп (Литвинова 2012, с. 48, 100-101).

ГК II (23,0 \% загальної мінливості) розмежовує групи переважно за двома ознаками - КВШ з від’ємною кореляцією $(-0,677)$ та ІППШ з додатною $(0,681)$. Певну подібність серії Волошине, що отримала великі від'ємні значення компоненти за даною ГК $(-1,589)$, можна простежити як до половців з Луганської обл. $(-2,174)$, так і до черепів Переяславського району $(-1,128)$, а також до вибірки з могильника Мамай Сурка $(-2,112)$ у Нижній Наддніпрянщині, в якій за даними Л.В. Литвинової, монголоїдна домішка невелика (Литвинова 2012, с. 34).

Вказаний комплекс ознак розмістив досліджувану групу у лівій нижній частині координатного поля (рис. 2). Найближчими до Волошиного виявилися половецька вибірка з Луганської обл. та група Мамай Сурка XII-XV ст., але вона перебуває на такій відстані, що можна констатувати лише часткову подібність.

Третя ГК (16,6 \% загальної мінливості) розмежовує групи тільки за однією ознакою - НО. 


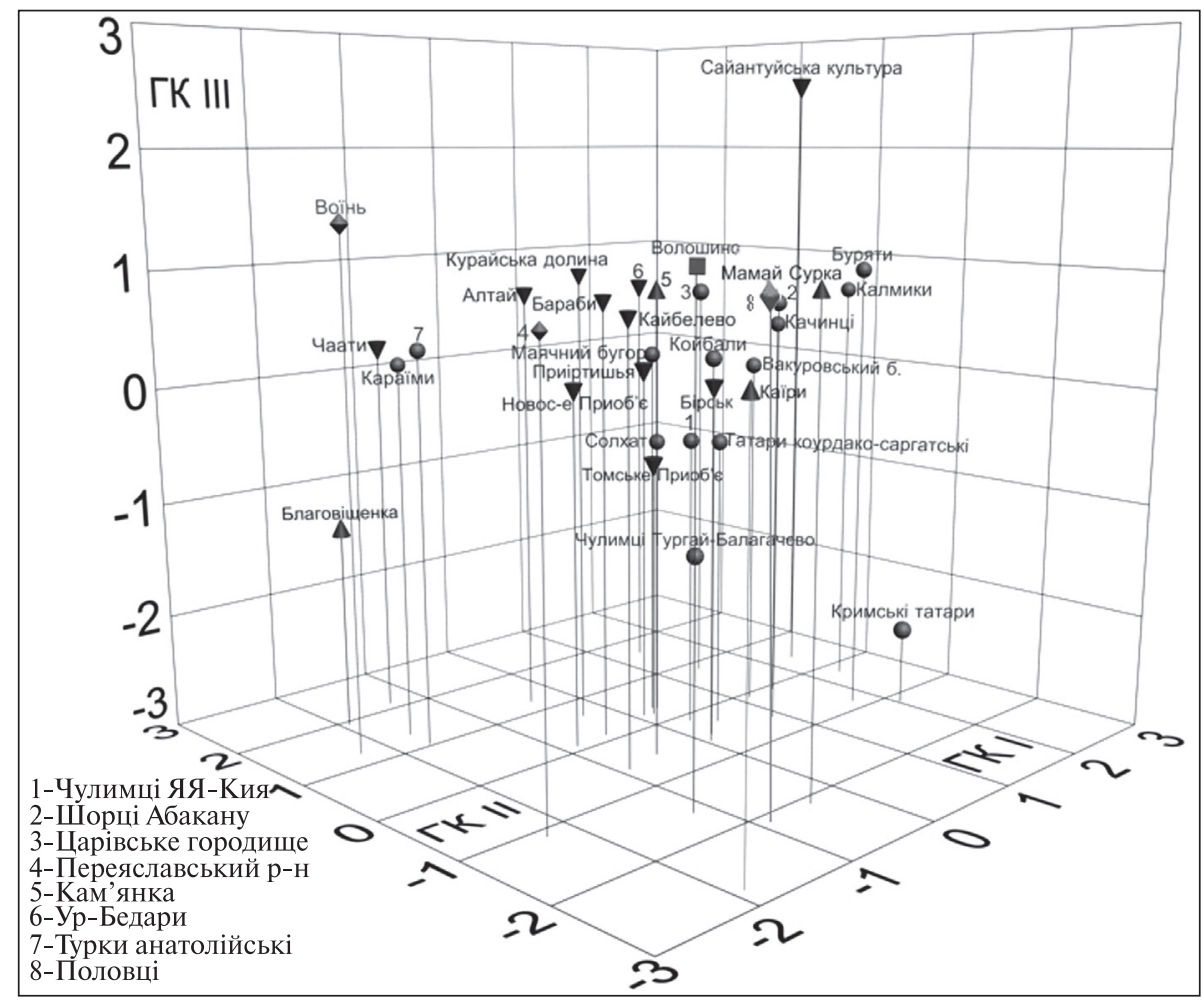

Puc. 3. Розташування 34 краніологічних груп XII-XVIII ст. у тривимірному простоpi. 1 - Чулимці ЯЯ-Кия; 2 - Шорці Абакану; 3 - Царівське городище; 4 - Переяславський р-н.; 5 - Кам'янка; 6 - Ур-Бедари; 7 - Турки анатолійські; 8 - половці

Fig. 3. Disposition of 34 craniological groups of $12^{\text {th }}-18^{\text {th }} \mathrm{c}$. in tridimensional space: $1-$ Chulyms of Yaya-Kyia; 2 - Shors of Abakan; 3 - Tsarev settlement site; 4 -Pereiaslav district; 5-Kamianka; 6-Ur-Bedary; 7-Anatolian Turks; 8-Cumans

За цією ГК Волошине отримує великі додатні значення $(0,732)$. Подібними виявились серії з Курайської долини на Алтаї $(0,726)$, Мамай Сурка з Нижньої Наддніпрянщини $(0,642)$ та меншою мірою, половці з Луганщини $(0,542)$ і група черепів з Нижньої Наддніпрянщини Кам'янка $(0,543)$ (рис. 3).

За даними кластерного багатовимірного аналізу (Дерябин 2008, с. 230-276) виявлено подібність вибірки черепів з Волошиного до серії половців на шостому кроці кластеризації (дистанція 0,430) із 33 (повна дистанція 4,610).

Отже, за трьома ГК виявлено найбільшу статистичну та морфологічну подібність черепів 3 могильника Волошине (дистанція - 1,178; $-1,589 ; 0,732)$ до половецької вибірки ХІXIII ст. з Луганської обл., (значення трьох ГК $-0,809 ;-2,174 ;-0,542)$ та, меншою мірою, до поховань із могильника Мамай Сурка $(-0,401$; -2,112; 0,642). Ці дані підтверджуються і кластерним аналізом. А.О. Козловський зауважив, що могильник Мамай Сурка залишило населення, яке мешкало у великому селищі та в етнічному плані було дуже змішаним (Козловський 1992). О.Б. Бубенок зазначав, що поруч із могильником Мамай Сурка існував великий економічний та торговельний центр, населення якого було як місцеве, так і прибуле з різних районів Золотої Орди (Бубенок 2004). На думку цього дослідника, в могильнику поховані й алани, які мали місцеве та північнокавказьке походження (Бубенок 2004; Литвинова 2004; Литвинова 2008).

Антропологічні матеріали, які входять до серії половців (Пришиб, Сміле й Знам'янка Слов'яносербського р-ну. Луганської обл.), дослідила К.А. Шепель 1992 р. Було подано статево-вікову і коротку краніометричну характеристику збірної серії кочовиків (Шепель 1992, с. 66). Як чоловіча, так і жіноча групи характеризуються гіпербрахікранією, малим висотним діаметром черепної коробки, широким чолом, високим і широким сплощеним обличчям. Орбіти помірної висоти, ніс вузький, слабо випнутий, з високим переніссям. При порівнянні цієї групи з відомими на той час серіями кочовиків епохи середньовіччя К.А. Шепель зазначила, що вибірка, яку вона дослідила, не знаходить собі повних аналогій, але має деяку подібність до окремих груп Середньої Азії, що належать до південносибірської раси, зокрема до серії хунну (Шепель 1992, с. 66). 
При дослідженні серії половців за шістьма ознаками краніоскопічної системи Ю.В. Долженко визначив, що збірна половецька серія демонструє поєднання ознак, що свідчить про iii азійське походження, особливо це помітно за потиличним індексом та ЗВШ, але слід констатувати і певну європеоїдну складову (ознаки НО і КВШ). Також упевнено можна зарахувати серію до південної групи (Долженко 2012, c. 137-140). У нашому випадку відзначається подібність вибірки половців та Волошине за ПІ, ПОВ-ІІ, КВШ та НО (табл. 2).

Подібність вибірки черепів Золотоординського часу з Волошиного до половецької групи XI-XIII ст. з Луганської обл. за даними краніоскопії важливе для розуміння участі етнічної групи половців у формуванні антропологічного типу населення Золотої Орди. Положення iї поряд з вибіркою Мамай Сурка XII-XIV ст. та половців дає підстави припустити, що грунтовий могильник Мамай Сурка переважно склався за рахунок половецької популяції. Подібної думки притримувалась C.О. Плетньова, яка припускала, що степові пам'ятки Наддніпрянщини належать змішаному бродницько-половецькому населенню (Плетнева 1981, с. 221). М.В. Квітницький наголошує, що грунтовий могильник Мамай Сурка переважно склався за рахунок половецької популяції (Братченко, Квитницкий, Швецов 2012, розділ III, с. 115-124).

Слід також зазначити, що за даними краніоскопії серія, з могильника Благовіщенка XII-XIV ст. при порівняльному аналізі виявилась дещо відмінною від інших груп Нижньої Наддніпрянщини (Кам'янка, Каїри та Мамай Сурка). Виявлено певну подібність цих груп до серії половців та золотоординців з Волошиного. Зауважимо, однак, що за результатами краніометричного аналізу відзначалась лише незначна подібність черепів з могильників Кам'янка, Каїри (Зіневич 1960, с. 98-101), Благовіщенка та Мамай Сурка до кочовиків Півдня України (Литвинова 2006, с. 302).

Висновки. У результаті застосування краніоскопічної методики до вивчення краніологічної серії поблизу с. Волошине виявлено, що ця група черепів містить більше європеоїдних ознак, а монголоїдна домішка проявилась переважно в потиличному індексі (ПІ) та певною мірою в надорбітних отворах (НО). Частота підорбітного візерунку типу II (ПОВ-II) на черепах із Волошиного низька, що свідчить про приналежність групи до південних європеоїдів. За етнічною краніоскопією, після ба- гатовимірного статистичного аналізу, в якому чоловічі й жіночі черепи розглядаються разом, виявлено, що досліджувана серія із с. Волошине XIII-XIV ст. тяжіє до половецької вибірки XI-XIII ст. з Луганської обл. та населення Нижньої Наддніпрянщини (Мамай Сурка XII-XV ст.), ніж до груп Волго-Уральського межиріччя чи до населення Забайкалля.

Подальше дослідження палеоантропологічного матеріалу з грунтових могильників Нижньої Наддніпрянщини та Золотої Орди може бути перспективним для висвітлення джерела формування морфологічного типу осілого населення Нижньої Наддніпрянщини та його зв'язків з золотоординцями.

Балабанова, М.А., Перерва, Е.В., Зубарева, Е.Г. 2011. Антропология Красноярского городища золотоордынского времени. Волгоград.

Балабанова, М.А., Перерва, Е.В. 2013. Маячный бугор, могильник Красноярского городища золотоордынского времени (антропология). Волгоград.

Братченко, С.Н., Квитницкий, М.В., Швецов, М.Л. 2012. Кочевники развитого средневековья на Северском Донце. Волинські старожитності. Київ.

Богусевич, В.А., Гончаров, В.К., Довженок, В.И., Килиевич, С.Р., Копылов, Ф.Б., Кучера, М.П., Юра, Р.А. Отчет о работах Кременчугской древнерусской археологической экспедиции Института археологии АН УССР в 1957 г. Полтавська обл. Науковий архів Iнституту археології НАН України. 1957/3.

Бодянський, О.В. 1977. Археологічні пам'ятки Запорізької та Дніпропетровської областей, які руйнуються водами озера ім. В.І. Леніна та Каховського водосховища. Науковий архів Інституту археології НАН України. 1977/89.

Бубенок, О.Б. 2004. Аланы-асы в Золотой Орде (ХІІІ$X V$ вв.). Киев.

Горбенко, С.О. 2006. Краніологічне дослідження та етнічна ідентифікація за черепом золотоординського кочівника 3 поховання 4 кургану 11 поблизу с. Волошине на Полтавщині. Додаток. 2. В: Супруненко О.Б. Кургани з похованнями золотоординського часу поблизу Волошиного у пониззі Псла. Старожитності околиць Комсомольська. Київ; Полтава, т. ІІІ, с. 113-135.

Громов, А.В., Моисеев, В.Г. 2004. Краниоскопия населения западной и южной Сибири: география и хронология. Расы и народы. 30, с. 216-248.

Дерябин, В.Е. 2008. Курс лекций по многомерной биометрии для антропологов. Москва.

Довженок, В.Й., Гончаров, В.К., Юра, Р.О. 1966. Древньоруське місто Воїнь. Київ.

Долженко, Ю.В. 2016. Краніологічна характеристика одного з похованих у кургані поблизу Кобелячка на Кременчуччині. Додаток 2. В: Супруненко О.Б. Курган поблизу с. Кобелячок на Кременчуччині. Свічадо Придніпров'я. Міський краєзнавчий Альманах. 10, с. 98-104.

Долженко, Ю.В. 2012. Краніоскопічна характеристика кочовиків-половців ХІ-ХІІІ ст. В: Братченко, С.Н., Квитницкий, М.В., Шведов, М.Л. Кочевники развитого средневековья на Северском Доние. Киев, с. 137-140.

Єльников, М.В. 2002. До питання про міграції за часів 3олотої Орди на Нижньому Дніпрі. Сучасні проблеми археології. Київ, с. 72-73. 
Єльников, М.В. 2006. До питання про кількість золотоординських городищ на Нижньому Дніпрі. Мат. мізкнар. наук. конф. «Північне Причорномор’я і Крим у добу середньовіччя (XIV-XV cm.)». Кіровоград, с. 45-51.

Ельников, М.В. 2006. Средневековый могильник МамайСурка (по материалам исследований 1993-1994 гг.). Запорожье, т. II.

Зіневич, Г.П. 1960. Матеріали до вивчення антропологічних особливостей черепів Каїрського могильника XI-XIII ст. Матеріали з антропологї України. Інститут мистецтвознавства, фольклору та етнографії. Київ, 1, с. 98-101.

Козинцев, А.Г. 1988. Этническая краниоскопия: расовая изменчивость швов черепа современного человека. Ленинград.

Козловський, А.О. 1992. Історико-культурний розвиток Південного Подніпров'я в XIX-XIV cm. Київ.

Колибенко, О.В. 2005. Історико-краєзнавчі дослідження Переяславщини (археологічні джерела). ПереяславХмельницький, т. 1.

Колибенко, О.В. 2015. Дослідження археологічних пам'яток Переяславської волості 11-13 ст. Наукові записки з укр. історії. с. 156-168.

Кондукторова, Т.С. 1957. Палеоантропологические материалы из средневекового Каменского могильника. Советская антропология. 1, с. 55-57.

Круц, С.І., Литвинова, Л.В. 2002. Антропологічна характеристика населення Нижнього Подніпров'я доби середньовіччя (за матеріалами могильника Благовіщенка). Сучасні проблеми археології. Київ, с. 115-117.

Круц, С.І., Литвинова, Л.В. 2003. Антропологічний склад населення Південного Подніпров'я за матеріалами могильника Благовіщенка. Археологічні відкриття 8 Україні 2001-2002 рр. Київ, 5, с. 143-149.

Крупа, Т.М. 2005. Дослідження шовкової парчі золотоординської доби з кургану 8, поховання 1 поблизу с. Волошине на Нижньому Пслі. Археологічний літопис Лівобережної України. 1-2, с. 103-107.

Кулатова, І.М., Скорий, С.А., Супруненко, О.Б. 2010. Кургани поблизу с. Волошине в пониззі Псла. Київ.

Литвинова, Л.В. 2004. Антропологічна характеристика населення Нижнього Подніпров'я доби середньовіччя (за матеріалами могильника Мамай Сурка). Археологія. 2, с. 68-78.

Литвинова, Л.В. 2008. Населення Нижнього Подніпров’я XII - початку XV ст. за антропологічними даними. Дис. ... канд. іст. наук. Київ, с. 80-83.

Литвинова, Л.В. 2012. Населення Нижнього Подніпров'я 12 - початку $15 \mathrm{~cm}$. Київ.

Литвинова, Л.В. 2006. Палеоантропологический материал из грунтового могильника Мамай Сурка (исследований 1993-1994 гг.). В: Ельников, М.В. Средневековый могильник Мамай-Сурка (по материалам исследований 1993-1994 гг.), Запорожье, т. II, с. 298-354.

Мироненко, К.М., Шилов, Ю.О. 2003. Золотоординські поховання на Кременчуччині. Археологічний літопис Лівобережної України. 2, с. 105-109.

Моисеев, В.Г., Широбоков, И.Г., Крийска, А., Хартанович, В.И. 2013. Краниологическая характеристика средневекового населения Эстонии. Радловский сборник. Научные исследования и музейные проекты МАЭ РАН в 2012 г. Санкт-Петербург, с. 71-79.

Моця, О.П. 2017. Золотоординські «темні» віки на землях Південної Русі: історико-археологічний контекст. Археологія. 2, с. 24-37.
Плетнева, С.А. 1981. Печенеги, торки, половцы. Степи Евразии в эпоху средневековья. Москва.

Рутківська, Л.М. 1975. Пам'ятки кочових племен Степового Подніпров'я IX-XIII ст. Археологія Украӥнської PCP. 3, c. 435-443.

Санкина, С.Л., Моисеев, В.Г. 2006. Александр Григорьевич Козинцев. Personalia. Антропологический форум. 5, c. $459-462$.

Сегеда, С.П. 2001. Антропологічний склад украӥнського народу. Етногенетичний аспект. Київ.

Сикорский, М.И., Махно, Е.В., Бузян, Г.Н. 1978. Отчет о работе Переяслав-Хмельницкой археологической экспедиции за 1978 г. Науковий архів Інституту археології НАН України. 1978/85.

Сикорский М.И., Махно Е.В., Бузян Г.Н. Отчет о работе Переяслав-Хмельницкой археологической экспедиции за 1983 г. Науковий архів Інституту археології НАН України. 1983/157, 1983.

Супруненко, А.Б., Маевская, С.В. 2010. Погребение золотоордынского времени с остатками костюма девочки-кочевницы на Нижнем Псле. Степи Европы в эпоху средневековья: Труды по археологии. Донецк, т. 8: Золотоордынское время, с. 295-340.

Супруненко, О.Б. 2013. Нові матеріали з пониззя Псла. Праці центру пам'яткознавства. 24, с. 153-167.

Супруненко, О.Б. 2016. Курган поблизу с. Кобелячок на Кременчуччині. Свічадо Придніпров'я. Міський краєзнавчий Альманах. 10, с. 81-97.

Супруненко, О.Б., Артем'єв, А.В., Маєвська, С.В. 2005. Унікальний комплекс золотоординського часу поблизу Волошиного. Київ; Полтава.

Супруненко, О.Б., Маєвська, С.В., Артем'єв, А.В., Горбенко, С.О. 2006. Кургани з похованнями золотоординського часу поблизу Волошиного у пониззі Псла. Київ; Полтава, ч. III.

Супруненко, О.Б., Приймак, В.В., Мироненко, К.М. 2004. Старожитності золотоординського часу Дніпровського лісостепового Лівобережжя. Київ; Полтава.

Супруненко, О.Б., Шерстюк, В.В., Пуголовок, Ю.О. Звіт про дослідження групи курганів поблизу кол. Хут. Дуканичі біля с. Волошине Дмитрівської сільської ради м. Комсомольськ Полтавської обл. на пром. майданчику Єристівського кар'єру ВАТ «Полтавський ГЗК» у 2009 р., 2009/278. Науковий архів Інституту археологї НАН Украӥни.

Толочко, П.П. 1998. Про походження й побутування терміну «Україна». Археологічний Літопис Лівобережної України. Полтава, 1-2 (3-4), c. 3-4.

Томашевич, Т.В. 1988. Закономерности распределения частот подглазничных каналов черепа человека. Boпросы археологии. 80, с. 119-128.

Шепель, Е.А. 1992. Антропологическая характеристика кочевников по материалам могильника у с. Пришиб. «Степи Восточной Европы во взаимосвязи Востока и Запада в средневековье» (тез. докл.) междунар. науч. семинар. Донецк.

Dolzhenko, Yu.V. 2015. Die bevölkerung der stadt Woyin XIIXIV jh. nach kraniologiedaten. East European Scientific Journal. Wschodnioeuropejskie Czasopismo Naukowe. Warszawa, Polska, czesc III, p. 95-102.

Kozintsev, A. 1992. Homo. Ethnic Epigenetic: a New Approach Ethnische Epigenetik, Vol. 43/3. Jena, New York, p. 213244.

Надійшла 12.02.2019 
Junior Researcher of the Department of bioarchaeology Institute of Archaeology, of the National Academy of Sciences of Ukraine, Kyiv,ORCID0000-0001-9807-2835, yuriy_dolzhenko@ukr.net

\section{THE GOLDEN HORDE NOMADS FROM THE NECROPOLIS NEAR VOLOSHYNE VILLAGE}

Monuments of the Golden Horde history had become well-known recently in Poltava region, especially in its steppe districts (in the lower basins of the Sula, Psel, Suhy Kobeliachok, Vorskla and Oril rivers). The crossings on Dnieper, Psel and Vorskla functioning in developed Medieval Period and at the beginning of the Late Medieval Period have caused emergence of nomads' camps. The camps maintained and protected roads and crossings as well as, probably, sustained customs on the banks of the Dnieper, near submerged Perevolochna, Keleberda and Kremenchuk. The Protective archaeological expedition of Centre for the Protection and Investigation of Archaeological Sites (Cultural Department of Poltava Regional State Administration) have explored the grave mounds of the Group 2 on a piece of land intended for ferruginous quartzite quarry of the company "Ferrexpo Yeristovo Mining" in July - September 2003 and in summer 2005. The works were carried out 7,0$7,2 \mathrm{~km}$ to the north and north-east of Horishni Plavni (former Komsomolsk) between the villages of Dukanychi, Voloshyne and Solontsi (Dmytriv village council of Horishni Plavni municipality, Poltava region). As a result, anthropological material has been given to the author's study. After studying of 46 skulls and their parts (period of the Golden Horde, Voloshyne area) it was found out, that the frequency of the 2 nd type of underorbital patterns on the skulls from Voloshyne is low. It is a feature of the Southern Caucasians. The indexes of sphenomaxillary suture are moderate. Occipital index from the grave field under investigation is increased according to the percentage (eastern vector of connections). Posterior zygomatic suture on the skulls of probed group is absent. It is typical for the Caucasians. Index of transverse palatine suture is moderate and indicates the series as a border-line between Caucasians and Mongoloids according to the mentioned feature and closer to European populations. The percentage of supraorbital foramens on the skulls is increased (eastern vector of connections). Multivariate principal component analysis has shown that the explored series is closer not to the groups of the interfluve of the Volga and Ural, Kurai valley or Transbaikal, but to people from the Lover Dnieper basin (Mamay Surka) according to ethnical cranioskopy, when male and female skulls are considered together.

K e y w o $r d$ s: the Golden Horde, nomads, Poltava region, Lower Psel basin, burial, cranioskopy, Voloshyne village, craniology.

\section{Ю.В. Долженко}

Младший научный сотрудник отдела биоархеологии ИА НАНУ, ORCID 0000-0001-9807-2835, yuriy_dolzhenko@ukr.net

\section{ЗОЛОТООРДЫНСКИЕ КОЧЕВНИКИ ПО МАТЕРИАЛАМ НЕКРОПОЛЯ ВОЗЛЕ с. ВОЛОШИНО}

Памятники золотоордынского времени за последние годы стали хорошо известны в степных районах Полтавщины - в низовьях Сулы, Псла, Сухого Кобелячка, Ворсклы и Орели. Днепровские, Пселская и Ворсклинская переправы, действовавшие в эпоху развитого и в начале позднего средневековья, обусловили появление здесь стойбищ кочевников, обеспечивавших функционирование и охрану дорог и переправ, возможно, также работу таможен на берегах Днепра. В июле-сентябре 2003 и в 2005 г. Охранная археологическая экспедиция Центра охраны и исследований памятников археологии управления культуры Полтавской облгосадминистрации исследовала курганы и курганные насыпи между сс. Дуканичи, Волошино и Солонцы Полтавской обл. Антропологический материал включает 46 скелетов. После обработки 46 черепов и их фрагментов (23 мужских и 22 женских, 1 - неопределенного пола) установлено, что частота подорбитного узора типа II (ПОВ-II) на черепах из Волошино низкая. Это указывает на принадлежность группы к южным европеоидам. Показатели клиновидного верхнечелюстного шва (КВШ) оказались умеренными. Затылочный индекс (ЗИ) из исследуемого могильника по процентной доле повышен (восточное направление связи); Задневисочный шов (ЗВШ) на черепах исследуемой группы отсутствует, что указывает на ее европеоидность. По данным умеренного индекса поперечно-небного шва (ИПНШ) можно считать исследуемую серию пребывающей на стыке между европеоидными и монголоидными показателями по данному признаку, но тяготеющую к европеоидным популяциям. Проценты надорбитных отверстий (HO) на черепах повышены, что указывает на восточный вектор связей этой группы людей. По данным многомерного анализа главных компонент выявлено, что исследуемая серия черепов из Волошино XIII-XIV вв. больше тяготеет к половецкой группы XI-XIII вв. из Донецкой обл. и населению Нижнего Поднепровья (Мамай Сурка XII-XV вв.).

Ключ е в ы е сло в а: Золота Орда, кочевник, Полтавщина, Волошино, низовья Псла, погребение, краниоскопия, краниология.

\section{References}

Balabanova, M.A., Pererva, E.V. 2013. Maiachnyi bugor mogilnik Krasnoiarskogo gorodishha zolotoordynskogo vremeni (antropologiia). Volgograd.

Balabanova, M.A., Pererva, E.V., Zubareva, E.G. 2011. Antropologiia Krasnoiarskogo gorodishha zolotoordynskogo vremeni. Volgograd. 
Bodianskyi O.V. Arkheolohichni pamiatky Zaporizkoi ta Dnipropetrovskoi oblastei, yaki ruinuiutsia vodamy ozera im. V.I. Lenina ta Kakhovskoho vodoskhovyshcha. Naukovyi arkhiv IA NANU. 1977/89.

Bogusevich V.A., Goncharov V.K., Dovzhenok V.I., Kilievich S.R., Kopylov F.B., Kuchera M.P., Jura R.A. Otchet o rabotakh Kremenchugskoi drevnerusskoi arheologicheskoi ekspeditsii Instituta arheologii AN USSR v 1957 g. Poltavskaia obl. Naukovyi arkhiv IA NANU, f. e., 1957/3.

Bratchenko, S.N., Kvitnickii, M.V., Shvetsov, M.L. 2012. Kochevniki razvitogo srednevekovia na Severskom Dontse. Kyiv.

Bubenok, O.B. 2004. Alany-asy v Zolotoi Orde (XIII-XVvv.). Kyiv.

Deriabin, V.E. 2008. Kurs lekcii po mnogomernoi biometrii dlia antropologov. Moskva.

Dolzhenko, Yu.V. 2015. Die bevölkerung der stadt Woyin XII-XIV jh. nach kraniologiedaten. East European Scientific Journal. Wschodnioeuropejskie Czasopismo Naukowe, III. pp. 95-102.

Dolzhenko, Yu.V. 2016. Kraniolohichna kharakterystyka odnoho z pokhovanykh u kurhani poblyzu Kobeliachka na Kremenchuchchyni. Dodatok 2 u statti Suprunenka O. B. Kurhan poblyzu s. Kobeliachok na Kremenchuchchyni. Svichado Prydniprovia. Miskyi kraieznavchyi Almanakh, 10, pp. 98-104.

Dolzhenko, Yu.V. 2013. Kranioskopichna kharakterystyka kochovykiv-polovtsiv XI-XIII st. Bratchenko S.N., Kvitnitskii M.V., Shvedov M.L. Kochevniki razvitogo srednevekovia na Severskom Dontse. Kyiv, pp. 137-140.

Dovzhenok, V.Y., Honcharov, V.K., Yura, R.O. 1966. Drevnoruske misto Voin. Kyiv.

Elnikov, M.V. 2006. Srednevekovoi mogilnik Mamai-Surka (po materialam issledovanii 1993-1994 gg.). Zaporizhzhia, vol. II.

Gromov, A.V., Moiseev, V.G. 2004. Kranioskopiia naseleniia zapadnoi i yuzhnoi Sibiri: geografiia i khronologiia. Rasy $i$ narody. 30, pp. 216-248.

Horbenko, S.O. 2006. Kraniolohichne doslidzhennia ta etnichna identyfikatsiia za cherepom zolotoordynskoho kochivnyka z pokhovannia 4 kurhanu 11 poblyzu s. Voloshyne na Poltavshchyni. Suprunenko O.B. Kurhany z pokhovanniamy zolotoordynskoho chasu poblyzu Voloshynoho u ponyzzi Psla. Starozhytnosti okolyts Komsomolska. Kyiv; Poltava, vol. III, pp. 113-135.

Kolybenko, O.V. 2015. Doslidzhennia arkheolohichnykh pamiatok Pereiaslavskoi volosti 11-13 st. Naukovi zapysky z ukr. istorii. 37, pp. 156-168.

Kolybenko, O.V. 2005. Istoryko-kraieznavchi doslidzhennia Pereiaslavshchyny (arkheolohichni dzherela). Pereiaslav-Khmelnytskyi, vol. 1.

Konduktorova, T.S. 1957. Paleoantropologicheskie materialy iz srednevekovogo Kamenskogo mogilnika. Sovetskaia antropologiia. 1, pp. 55-57.

Kozintsev, A.G. 1988. Etnicheskaia kranioskopiia: rasovaia izmenchivost shvov cherepa sovremennogo cheloveka. Leningrad.

Kozintsev, A. 1992. Homo. Ethnic Epigenetic: a New Approach Ethnische Epigenetik, 43/3, pp. 213-244.

Kozlovskyi, A.O. 1992. Istoryko-kulturnyi rozvytok Pivdennoho Podniprovia v XIX-XIV st. Kyiv.

Krupa, T.M. 2005. Doslidzhennia shovkovoi parchi zolotoordynskoi doby z kurhanu 8, pokhovannia 1 poblyzu s. Voloshyne na Nyzhnomu Psli. Arkheolohichnyi litopys Livoberezhnoi Ukrainy. 1-2, pp. 103-107.

Kruts, S.I., Lytvynova, L.V. 2002. Antropolohichna kharakterystyka naselennia Nyzhnoho Podniprovia doby serednovichchia (za materialamy mohylnyka Blahovishchenka). Suchasni problemy arkheolohii. pp. 115-117.

Kruts, S.I., Lytvynova, L.V. 2003. Antropolohichnyi sklad naselennia Pivdennoho Podniprovia za materialamy mohylnyka Blahovishchenka. Arkheolohichni vidkryttia v Ukraini 2001-2002 rr., 5, pp. 143-149.

Kulatova, I.M., Skoryi, S.A., Suprunenko, O.B. 2010. Kurhany poblyzu s. Voloshyne v ponyzzi Psla. Starozhytnosti okolyts Komsomolska, VIII.

Litvinova, L.V. 2006. Paleoantropologicheskii material iz gruntovogo mogilnika Mamai Surka (issledovanii 1993-1994 gg.). Razdel 2. Elnikov M.V. Srednevekovyi mogilnik Mamai-Surka (po materialam issledovanii 1993-1994 gg.). Zaporizhzhia, vol. II, pp. 298-354.

Lytvynova, L.V. 2004. Antropolohichna kharakterystyka naselennia Nyzhnoho Podniprovia doby serednovichchia (za materialamy mohylnyka Mamai Surka). Arkheolohiia. 2, pp. 68-78.

Lytvynova, L.V. 2012. Naselennia Nyzhnoho Podniprovia 12 - pochatku 15 st. Kyiv.

Lytvynova, L.V. 2008. Naselennia Nyzhnoho Podniprovia XII - pochatku XV st. za antropolohichnymy danymy. Dys. ... kandydata istorychnykh nauk. Kyiv.

Moiseev, V.G., Shirobokov, I.G., Kriiska, A., Khartanovich, V.I. 2013. Kraniologicheskaia kharakteristika srednevekovogo naseleniia Estonii. Radlovskii sbornik. Nauchnye issledovaniia i muzeinyie proekty MAE RANv $2012 \mathrm{~g}$. Sankt-Peterburg, pp. 71-79.

Motsia, O.P. 2017. Zolotoordynski “temni” viky na zemliakh Pivdennoi Rusi: istoryko-arkheolohichnyi kontekst. Arkheolohiia, 2, pp. 24-37.

Myronenko, K.M., Shylov, Yu.O. 2003. Zolotoordynski pokhovannia na Kremenchuchchyni. Arkheolohichnyi litopys Livoberezhnoi Ukrainy, 2. pp. 105-109.

Pletneva, S.A. 1981. Pechenegi, torki, polovtsy. Stepi Evrazii v epokhu srednevekovia. Moskva, pp. 202-239.

Rutkivska, L.M. 1975. Pamiatky kochovykh plemen Stepovoho Podniprovia IX-XIII st. Arkheolohiia Ukrainskoi RSR, 3, pp. 435443.

Sankina, S.L., Moiseev, V.G. 2006. Aleksandr Grigorevich Kozintsev. Personalia. Antropologicheskii forum. 5, pp. 459-462.

Seheda, S.P. 2001. Antropolohichnyi sklad ukrainskoho narodu. Etnohenetychnyi aspekt. Kyiv.

Shepel, E.A. 1992. Antropologicheskaia harakteristika kochevnikov po materialam mogilnika u s. Prishib. "Stepi Vostochnoj Evropy vo vzaimosviazi Vostoka i Zapada v srednevekove” (tezisy dokladov) mezhdunarodnyi nauchnyi seminar. Donetsk, pp. 66. 
Sikorskii M.I., Makhno E.V., Buzian G.N. Otchet o rabote Pereiaslav-Khmelnickoi arheologicheskoi ekspeditsii za 1978 g. Naukovyi arkhiv Instytutu arkheolohii NAN Ukrainy. f. e., 1978/85.

Sikorskii M.I., Makhno E.V., Buzian G.N. Otchet o rabote Pereiaslav-Khmelnitskoi arheologicheskoi ekspeditsii za 1983 g. Naukovyi arkhiv Instytutu arkheolohii NAN Ukrainy. f. e., 1983/157.

Sukhobokov, O.V. 1989. Pivdenno-skhidne porubizhzhia davnoruskoi derzhavy v VIII-XIII st. Arkheolohiia. 3, pp. 50-59.

Suprunenko, A.B., Maevskaia, S.V. 2010. Pogrebenie zolotoordynskogo vremeni s ostatkami kostiuma devochki-kochevnitsy na Nizhnem Psle. Stepi Evropy v epokhu srednevekovia: Trudy po arkheologii. Donetsk, vol. 8, pp. 295-340.

Suprunenko, O.B. 2016 Kurhan poblyzu s. Kobeliachok na Kremenchuchchyni. Svichado Prydniprovia. Miskyi kraieznavchyi Almanakh. 10, pp. 81-97.

Suprunenko, O.B. 2013. Novi materialy z ponyzzia Psla. Pratsi tsentru pamiatkoznavstva. 24, pp. 153-167.

Suprunenko, O.B., Artemiev, A.V., Maievska, S.V. 2005. Unikalnyi kompleks zolotoordynskoho chasu poblyzu Voloshynoho. Kyiv; Poltava.

Suprunenko, O.B., Maievska, S.V., Artemiev, A.V., Horbenko, S.O. 2006. Kurhany z pokhovanniamy zolotoordynskoho chasu poblyzu Voloshynoho u ponyzzi Psla. Kyiv; Poltava.

Suprunenko, O.B., Pryimak, V.V., Myronenko, K.M. 2004. Starozhytnosti zolotoordynskoho chasu Dniprovskoho lisostepovoho Livoberezhzhia. Kyiv; Poltava.

Suprunenko O.B., Sherstiuk V.V., Puholovok Yu.O. Zvit pro doslidzhennia hrupy kurhaniv poblyzu kol. Khut. Dukanychi bilia s. Voloshyne Dmytrivskoi silskoi rady m. Komsomolsk Poltavskoi obl. na prom. maidanchyku Yerystivskoho karieru VAT "Poltavskyi HZK" u 2009 r. Naukovyi arkhiv Instytutu arkheolohii NAN Ukrainy. f. e., 2009/278.

Tolochko, P.P. 1998 Pro pokhodzhennia y pobutuvannia terminu "Ukraina”. Arxeologichnyi Litopys Livoberezhnoyi Ukrainy. 1-2 (3-4), pp. 3-4.

Tomashevich, T.V. 1988 Zakonomernosti raspredeleniia chastot podglaznichnykh kanalov cherepa cheloveka. Voprosy arkheologii. 80, pp. 119-128.

Yelnykov, M. 2006. Do pytannia pro kilkist zolotoordynskykh horodyshch na Nyzhnomu Dnipri. Mat. mizhnar. nauk. konf. "Pivnichne Prychornomoria i Krym u dobu serednovichchia (XIV-XV st.)". Kirovohrad, pp. 45-51.

Yelnykov, M.V. 2002. Do pytannia pro mihratsii za chasiv Zolotoi Ordy na Nyzhnomu Dnipri. Suchasni problemy arkheolohii. Kyiv, pp. $72-73$.

Zinevych, H.P. 1960. Materialy do vyvchennia antropolohichnykh osoblyvostei cherepiv Kairskoho mohylnyka XI-XIII st. Materialy z antropolohii Ukrainy. 1, pp. 98-101. 